\title{
77 .オープンスペースの照明形態の違いを考慮した利用者行動分析
}

\author{
○小林秀明 \\ (筑波大学大学院)
}

深堀清隆＼cjkstart窪田陽一

(埼玉大学)
田中晶子

（復建エソジニヤリング）

\section{1. はじめに}

都市空間においてはライフスタイルの多様化により夜間の活動時間が増加する傾向にある。歩行者 にとっては、より快適で空間利用形態にあった照明への関心が高まり、適切な照明環境の形成が重要 な課題にされるようになってきた。夜間街路の歩行者たちは様々な用途を持ち、街路に付随する公開 空地やその他ポケットパークなどのオープンスペースでは純粋な歩行目的以外の行動も観測される。

本研究では、街路中にあるオープンスペースの利用形態を心理的実験を通じて調査した。照明環境 を実験的にコントロールしながら、その中での光の効果の多様性を評価し、同時に人々の行動にどの ような影響を及ぼすのかを検証した。

\section{2. 実験概要及び方法}

広場の照明環境について既設の設置事例を参考にし、光のボリュームが卓越している位置の違いに より、広場の照明形態を 4 種類に分類し、以下のように定義した。(1)光源卓越型 : 上方部にある光源 が卓越している広場 (2)囲繞面卓越型 : 囲繞面を照らす光が卓越している広場(3)グラウンド卓越型 : 地面を照らす光が卓越している広場(4)アイストップ卓越型 : アイストップへの光が卓越している広 場。これら 4 タイプの広場ついて、照明器具の配置方法、均斉度を変えた全 8 パターン(表 1$)$ によ り作られる照明環境 54 パターンを抽出し、C Gを用い作成した(図 2 )。ひとつの広場について「鳥 瞰図」「入り口からの広場風景」「広場内ベンチからの広場風景」の 3 画像を用意し、その広場で どのような行動をとりたいと思うかを回答してもらった。行 動は図 1 のように、基本行動形態と行動目的の組み合わせで 表現されている。

\section{$\star$ 方法}

被験者数 : 39 名（男: 30 名、女 : 9名）

被験者構成 : 埼玉大学工学部建設工学科 $1 \sim 4$ 年生

画像提示方式: 54 パターンの広場について「鳥瞰図(広場全 体図) 、「入口からの広場風景」、「広場手前左側ベンチから の広場風景」の 3 枚の画像を用意した。被験者にはこの広場 の入口に立っている事をイメージしても らい、回答用紙にある様々な行動がその広 場にふさわしいかどうか判断し、ふさわし いと思う行動を全てチェックしてもらう。 * 広場の画像は順不同に提示、回答用紙 は 1 画像につき 1 枚用意

\section{3. データ集計処理}

アンケート調査によって得られたデータ を(1)基本行動別および(2)行動目的別に見て、 その傾向の違いについて考察を加える。考 察の基となるデータは、被験者が各画像に おいて回答した各々の行動の集計值で、4 つの照明形態と 5 種の基本行動および $3 つ$ の行動目的でそれぞれクロス集計を行った。 4 つの照明形態に属する画像数は異なるの

\begin{tabular}{|c|c|c|}
\hline 画像1 & $p=$ 杜 & 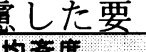 \\
\hline $\begin{array}{l}\text {-ポール灯 } \\
\text { - 囲繶面への投光 }\end{array}$ & - 整列 & - $6-$ \\
\hline •フットライト & •ランダム & בב \\
\hline
\end{tabular}

で得られた集計值は 1 つの画像あたりの平均値となっている。基本行動別の集計結果を図 4 に、行動 目的別集計結果は図 5 に示した。

Analysis of pedestrian behavior in openspace with various style of lighting Hideaki Kobayashi, Kiyotaka Fukahori and Yoichi Kubota, Akiko Tanaka 

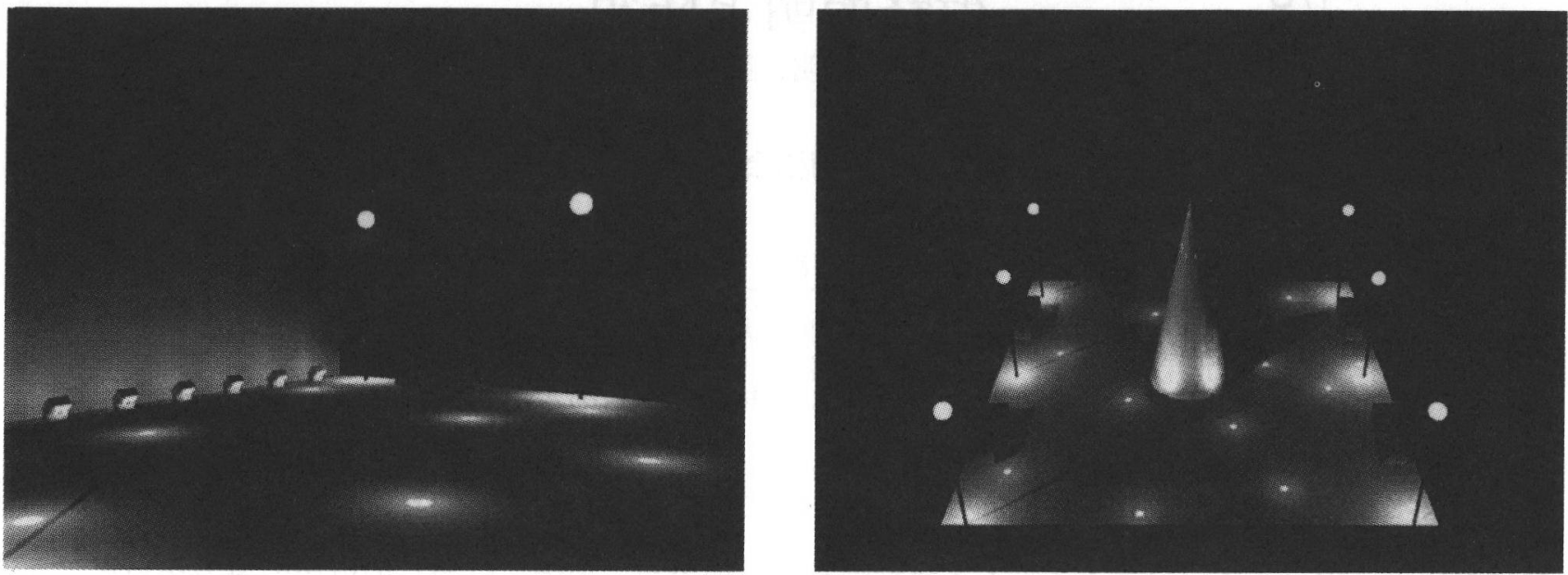

図2.シミュレーション画像例

\section{4. 結果及び考察}

図 3 を見るとアイストップ卓越型は回答行動数が全体として 多く、行動誘発力が高いと分かる。対称的に、囲繞面卓越型は 行動自体をあまり誘発していない。適度な囲繞感は滞留を目的 とした行動を誘発する作用があると思われるが、全体としては 行動意欲が低くなるものと推察される。光源卓越型やグラウン ド卓越型はほぼ平均的な行動を誘発している。しかし、この 2 タイプの相違は図 4 より、光源卓越型では中に入る行動より立 ち止まるタイプの行動が多数なのに対し、グラウンド卓越型は 全く逆の傾向を示している。中に入るタイプの行動は立ち止ま るタイプの行動より活動的なものが多く、グラウンド面を明る くする事により夜間においてもアクティビティーが誘発される ものと解釈できる。この照明形態ではスポーツやパフォーマン スなどグラウンド卓越型本来の場の利用としての機能が期待で きる。待ち合わせ行動はアイストップ卓越型においてよく観測 されることが確認される。

次に図 5 により目的別の行動誘発数をみると囲繞面卓越型及 びグラウンド卓越型がその場の視覚的特徴をアピールするとい う面で被験者は空間力を感じている事が分かる。空間力とは閉 鎖的広場の照明など空間構成要素が視覚的に行動者を惹きつけ る力である。光源卓越型では空間力もさることながら、 Relax が他の 3 タイプより多い。特にベンチなどの滞留スペース付近 では、上方の点光源を除いて光の卓越のない方が、落ち着きが 出るものと解釈できる。また囲繞面卓越型に関しては、囲まれ 感により Relax タイプが最も誘発されると当初は推測されてい た。しかし、シミュレーションでは現実の夜間の閉鎖的空間を 再現するのが困難であった。そのため光を受けた囲繞面が被験 者に対し、必要以上に落ち着きのなさや威圧感を感じさせてし まったものと思われる。

\section{5.まとめ}

今回のシミュレーション画像の作成では利用形態と人間の行

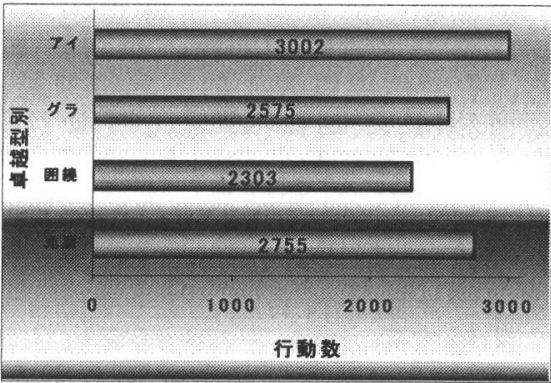

図 3 .卓越型別行動数

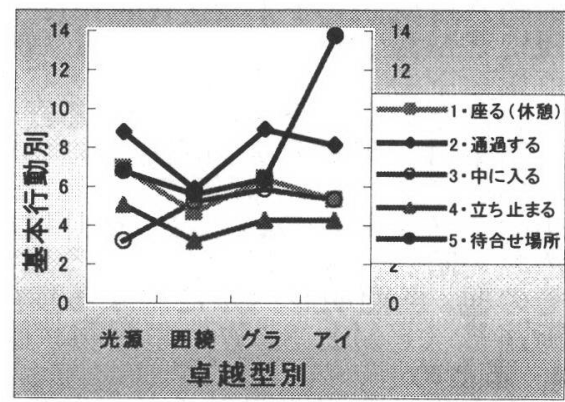

図 4 .卓越型別基本行動

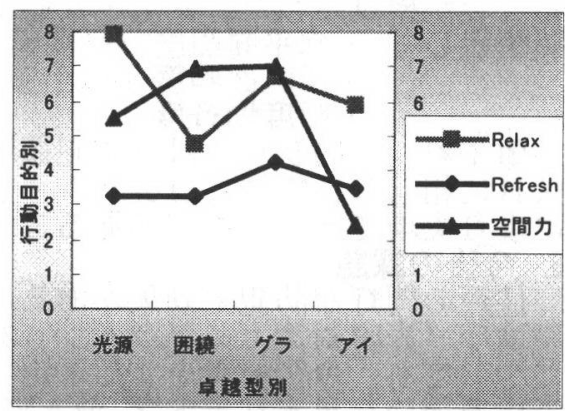

図 5 .卓越型別行動目的 動の関係を分析するために 54 枚の照明シミュレーション画像を作成して実験を行った。結果を見る と、様々な行動がどのような照明形態であると期待されるのかがある程度判明した。これはオープン スペースの照明デザインを実施するときに参考になるものと思われる。しかしより現実に近い照明シ ミュレーションを実施して被験者に正確な空間認知をしてもらうようにする必要性を感じた。 